\title{
Study on Predication of Air-conditioning Energy Consumption in University Teaching Buildings
}

\author{
Chunzhen Qiao ${ }^{1}$, Tingrui Yang ${ }^{1}$, Chunxia $\mathrm{Jia}^{2}$ \\ ${ }^{1}$ Department of Civil Engineering, North China University of Technology, Beijing, 100144, China \\ ${ }^{2}$ Jianke EET Co., Ltd, Beijing, 100013, China
}

\begin{abstract}
In this paper, the summer air conditioning cooling load of a university teaching building in Beijing is analyzed by orthogonal experiment and DeST energy consumption simulation method, and the primary and secondary relationship and significance level of the factors affecting cooling load are obtained, which can provide energy-saving design Focus. At the same time, through regression analysis of the test results, the summer cooling load prediction equation of the teaching building is obtained, and the error analysis of the equation is performed to verify the linear correlation of the equation. The prediction equation can be used to quickly and simply evaluate and analyze the effects of different design strategies on teaching the influence of building summer cooling load.
\end{abstract}

\section{Introduction}

In the context of the popularization of higher education, the number of colleges and universities is increasing, and the energy consumption of colleges and universities is also increasing rapidly. A survey shows that the energy consumption of colleges and universities accounts for about $8 \%$ of the total energy consumption of society, and the average energy consumption is about twice the national average energy consumption per capita, of which the highest can be as much as 4 times [1-2]. Compared with the energy consumption of other public buildings, the energy consumption of university teaching buildings changes periodically with the seasons, the energy consumption during holidays is significantly reduced, and the distribution of teachers and students is concentrated, the indoor energy consumption is large, and the energy consumption per capita is high [3]. In the " Assessment standard for green campus " promulgated by the Ministry of Housing and Urban-Rural Development in 2019, the evaluation content and indicators for green campuses in colleges and universities are put forward, and the energysaving work of colleges and universities has been put on the agenda [4]. The energy consumption of campus buildings with different design styles can be calculated by simulation software [5], but in the early design stage of the building, many design factors are still unclear, and software simulation methods are also limited. Therefore, this paper studies the impact of different levels of factor combinations on building energy consumption, explores the significant level differences between various design factors, and proposes a prediction equation for summer air-conditioning energy consumption indicators.

\section{Experimental design and energy consumption simulation}

The energy consumption of public buildings mainly consists of heating, air conditioning lighting office electrical equipment and special functional equipment. The energy consumption of air conditioning system can reach $40 \%-60 \%$ of the total energy consumption of the building [6], which is an important part of the total energy consumption of the building, and it is also a key consideration for energy-saving design. The influencing factors of air-conditioning energy consumption include: envelope structure materials, building orientation, building shading, shape coefficient, window-wall ratio, indoor thermal disturbance and many other factors. The number of experiments to simulate building energy consumption under the complete cross-matching of all levels is very large. If the orthogonal experiment method is used, only a few representative combinations need to be selected as samples, and correct and effective conclusions can be obtained through scientific analysis.

\subsection{Orthogonal experimental design}

Based on the research and analysis of previous scholars and the simplification of the actual model, this paper selects 6 experimental factors, regardless of the interaction between the factors, and selects the orthogonal table of $\mathrm{L}_{16}\left(4^{4} \times 2^{2}\right)$ [7]. The factors and levels selected in this paper are shown in Table 1 below. $\mathrm{RC}$ - -reinforced concrete, PFB—polystyrene foam board.

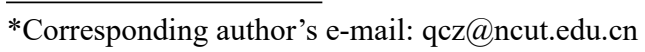


Table 1. Factors and level settings.

\begin{tabular}{|c|c|c|c|c|c|c|c|c|}
\hline \multirow{2}{*}{ Factor } & \multicolumn{8}{|c|}{ Level } \\
\hline & 1 & Value & 2 & Value & 3 & Value & 4 & Value \\
\hline $\begin{array}{c}\text { A (outer wall } \\
\text { materials } \\
\mathrm{W} / \mathrm{m}^{2} \cdot \mathrm{K} \text { ) }\end{array}$ & $\begin{array}{c}200 \mathrm{~mm} \mathrm{RC} \\
\text { wall }+50 \mathrm{~mm} \\
\text { PFB }\end{array}$ & 0.744 & $\begin{array}{c}200 \mathrm{~mm} \mathrm{RC} \\
\text { wall }+40 \mathrm{~mm} \\
\text { PFB }\end{array}$ & 0.884 & $\begin{array}{c}200 \mathrm{~mm} \mathrm{RC} \\
\text { wall }+30 \mathrm{~mm} \\
\text { PFB }\end{array}$ & 1.088 & $\begin{array}{c}200 \mathrm{~mm} \mathrm{RC} \\
\text { wall }+20 \mathrm{~mm} \\
\text { PFB }\end{array}$ & 1.416 \\
\hline $\begin{array}{l}\mathrm{B}(\text { Roof } \\
\text { materials } \\
\left.\mathrm{W} / \mathrm{m}^{2} \cdot \mathrm{K}\right)\end{array}$ & $\begin{array}{c}100 \mathrm{~mm} \\
\mathrm{RC}+50 \mathrm{~mm} \\
\text { PFB }\end{array}$ & 0.779 & $\begin{array}{l}100 \mathrm{~mm} \\
\mathrm{RC}+40 \mathrm{~mm} \\
\text { PFB }\end{array}$ & 0.934 & $\begin{array}{c}100 \mathrm{~mm} \\
\mathrm{RC}+30 \mathrm{~mm} \\
\text { PFB }\end{array}$ & 1.116 & $\begin{array}{c}100 \mathrm{~mm} \mathrm{RC} \\
+20 \mathrm{~mm} \text { PFB }\end{array}$ & 1.551 \\
\hline $\begin{array}{c}\mathrm{C} \text { (outer windor } \\
\text { materials } \\
\left.\mathrm{W} / \mathrm{m}^{2} \cdot \mathrm{K}\right)\end{array}$ & $\begin{array}{c}\text { Vacuum }+ \\
\text { Low-e glass }\end{array}$ & 2.2 & $\begin{array}{l}\text { Standard } \\
\text { exterior } \\
\text { window }\end{array}$ & 2.5 & $\begin{array}{l}\text { Ordinary } \\
\text { hollow }\end{array}$ & 3.1 & $\begin{array}{l}\text { Ordinary } \\
\text { single glass }\end{array}$ & 5.7 \\
\hline $\begin{array}{l}\text { D (building } \\
\text { shading) }\end{array}$ & $\begin{array}{l}\text { Ordinary } \\
\text { curtains }\end{array}$ & 0.5 & Blinds & 0.6 & Dark curtains & 0.65 & No shade & 0 \\
\hline $\begin{array}{l}\text { E (shape } \\
\text { coefficient) }\end{array}$ & & $\begin{array}{c}11 \\
\text { floors }\end{array}$ & & $\begin{array}{c}13 \\
\text { floors }\end{array}$ & & & & \\
\hline $\begin{array}{l}\text { F (window- } \\
\text { wall ratio) }\end{array}$ & & 0.25 & & 0.2 & & & & \\
\hline
\end{tabular}

\subsection{Energy consumption simulation}

Building energy consumption simulation uses DeST software developed by Tsinghua University, which uses a multi-zone calorific value balance algorithm to dynamically simulate the thermal process of the room. According to the designed orthogonal table, the experimental conditions under different combinations of different factors at different levels are simulated one after another.

\subsubsection{Building model}

The research object is a university teaching building in Beijing. The climate is divided into cold areas, and the building is facing south. The building has 13 floors, each floor area is about $2230 \mathrm{~m}^{2}$. The height of the first to fourth floors of the building is $4.5 \mathrm{~m}$, and the height of the sixth and above floors is $4 \mathrm{~m}$. Room types include: classrooms, bathrooms, storage rooms, corridors, and duct wells. The shape coefficient of the teaching building is realized by changing the number of floors, which are 11 and 13 floors respectively. Except for the research factors, the types and levels of all parameters of the model remain unchanged. The indoor design temperature is $18^{\circ} \mathrm{C}$, the ventilation frequency is $0.5-2$ times $/ \mathrm{h}$, and the indoor personnel, lighting, equipment and other parameters are defaulted by DeST software.

\subsubsection{Simulation results}

After DeST simulation calculation, the calculation results of the building's summer air conditioning cooling load are shown in Table 2.
Table 2. Results of simulations.

\begin{tabular}{cccc}
\hline $\begin{array}{c}\text { Test } \\
\text { counts }\end{array}$ & $\begin{array}{c}\text { Cooling load of } \\
\text { air conditioning } \\
\text { in summer }(\mathrm{W} /\end{array}$ & $\begin{array}{c}\text { Test } \\
\text { counts } \\
\left.\mathrm{m}^{2}\right)\end{array}$ & $\begin{array}{c}\text { Cooling load of } \\
\text { air conditioning } \\
\text { in summer }(\mathrm{W} / \\
\left.\mathrm{m}^{2}\right)\end{array}$ \\
\hline 1 & 22.76 & 9 & 18.68 \\
2 & 18.86 & 10 & 18.63 \\
3 & 21.38 & 11 & 21.58 \\
4 & 17.74 & 12 & 22.97 \\
5 & 19.95 & 13 & 23.02 \\
6 & 23.25 & 14 & 20.13 \\
7 & 22.13 & 15 & 19 \\
8 & 19.14 & 16 & 20.45 \\
\hline
\end{tabular}

\section{Result analysis}

\subsection{Range analysis}

Table 3 shows the results of range analysis. $y_{j k}$ is the sum of test indicators corresponding to the k level of factor $\mathrm{j}$, $\bar{y}_{j k}$ is the average value of $y_{j k}$, and $R_{j}$ is the range of factor $\mathrm{j}$. According to the required range result, the primary and secondary relationship of the factors can be analyzed, and the influence of each factor on the cooling load of the air conditioner can be judged. The larger the range, the more important the corresponding influence factor. The fourth column $\mathrm{D}$ has a range of 3.89 , which is the largest of all ranges. This column is to arrange $\mathrm{D}$ factor (building shading), indicating that D factor (building shading) has the greatest impact on the cooling load of air conditioning in summer. The remaining factors are arranged in descending order according to the degree of influence on the cooling load of summer air conditioning: $\mathrm{E}$ (shape coefficient) $>\mathrm{C}$ (outer window materials) $>\mathrm{F}$ 
(window-wall ratio) $>\mathrm{B}$ ( roof materials) $>\mathrm{A}$ (outer wall materials).

Table 3. Range analysis table.

\begin{tabular}{ccccccc}
\hline & $\mathrm{A}$ & $\mathrm{B}$ & $\mathrm{C}$ & $\mathrm{D}$ & $\mathrm{E}$ & $\mathrm{F}$ \\
\hline$y_{j 1}$ & 82.40 & 81.16 & 81.20 & 85.96 & 118.98 & 125.82 \\
$y_{j 2}$ & 82.00 & 81.52 & 83.28 & 74.56 & 128.28 & 121.44 \\
$y_{j 3}$ & 82.48 & 83.64 & 81.00 & 79.04 & & \\
$y_{j 4}$ & 82.84 & 83.36 & 84.20 & 90.12 & & \\
$\bar{y}_{j 1}$ & 20.60 & 20.29 & 20.30 & 21.49 & 19.83 & 20.97 \\
$\bar{y}_{j 2}$ & 20.50 & 20.38 & 20.82 & 18.64 & 21.38 & 20.24 \\
$\bar{y}_{j 3}$ & 20.62 & 20.91 & 20.25 & 19.76 & & \\
$\bar{y}_{j 4}$ & 20.71 & 20.84 & 21.05 & 22.53 & & \\
$R_{j}$ & 0.21 & 0.62 & 0.80 & 3.89 & 1.55 & 0.73 \\
\hline
\end{tabular}

\subsection{Variance analysis}

The range analysis method is simple and intuitive, but it cannot measure the degree of influence of different factor levels on the difference in the average value of the test indicators. Therefore, a further analysis of variance is carried out on the basis of the range analysis, and the data fluctuations caused by various accidental factors are distinguished from the data fluctuations caused by different test conditions, and it is judged whether the data fluctuations are mainly caused by the experimental errors or by the change of the experimental conditions, determine the credibility of the experimental optimization results. The analysis results are shown in the following table, and $\mathrm{F}$ is the ratio of the mean square of each factor to the mean square of error.

Table 4. Variance analysis table.

\begin{tabular}{cccc}
\hline Source of error & $\mathrm{F}$ & Sig & Significance level \\
\hline $\mathrm{A}$ & 96.673 & 0.075 & $*$ \\
$\mathrm{~B}$ & 1302.769 & 0.02 & $* *$ \\
$\mathrm{C}$ & 2016.51 & 0.016 & $* *$ \\
$\mathrm{D}$ & 39541.57 & 0.004 & $* * *$ \\
$\mathrm{E}$ & 31430.22 & 0.004 & $* * *$ \\
$\mathrm{~F}$ & 6889 & 0.008 & $* * *$ \\
\hline
\end{tabular}

Find out the corresponding associated probability $\mathrm{P}$ value according to the $\mathrm{F}$ distribution table, and judge the significance level of the factor. $0.05<\operatorname{Sig}(\mathrm{A})<0.1$, indicating that the change of factor $\mathrm{A}$ (outer wall materials) has a certain impact on the cooling load of airconditioning in summer, but the significance level is low, which can be used as a later consideration factor in the airconditioning energy-saving design. $0.01<\operatorname{Sig}(\mathrm{B} \& \mathrm{C})<0.05$, indicating that factors $\mathrm{B}$ (roof materials) and $\mathrm{C}$ (outer window materials) have a significant impact on the cooling load of air conditioning in summer, and certain energy-saving treatment measures should be taken into consideration when designing energy-saving schemes. $\operatorname{Sig}(\mathrm{D} \& E \& F)<0.01$, indicating that the factors D (building shading), E (shape coefficient) and $\mathrm{F}$ (window-wall ratio) have a highly significant impact on the change of air conditioning cooling load, and should be the primary factor to be considered in energy saving and consumption reduction. And the energy-saving benefits produced by changing the level of corresponding factors have great potential to be tapped.

\subsection{Regression analysis}

Origin is a powerful data analysis and scientific drawing software launched by Origin Lab. It is one of the software commonly used by scientific and technological workers. In this paper, Origin is used to perform multiple linear regression of the building summer air conditioning cooling load.

\subsubsection{The establishment of regression equation}

Before establishing the regression equation, according to the above-mentioned significance analysis conclusion, the influence of factor A (outer wall materials) on the seasonal cooling load of building air conditioning is ignored. Let factors B (roof materials), C (outer window materials), D (building shading), E (shape coefficient), and $\mathrm{F}$ (windowwall ratio) be the independent variables $\mathrm{X}_{1}, \mathrm{X}_{2}, \mathrm{X}_{3}, \mathrm{X}_{4}, \mathrm{X}_{5}$, and $\mathrm{Y}$ as the dependent variable to represent the summer air conditioning cooling load. If $\mathrm{Y}$ has a linear relationship with $\mathrm{X}_{1}, \mathrm{X}_{2}, \mathrm{X}_{3}, \mathrm{X}_{4}, \mathrm{X}_{5}$, a regression model can be established based on the knowledge of mathematical statistics:

$$
\begin{gathered}
y_{i}=\beta_{0}+\beta_{1} x_{i 1}+\beta_{2} x_{i 2}+\beta_{3} x_{i 3}+\beta_{4} x_{i 4}+\beta_{5} x_{i 5}+\varepsilon_{i} \\
(i=1,2, \ldots, N)
\end{gathered}
$$

Among them, $\beta_{0}, \beta_{1}, \ldots, \beta_{5}$ are the parameters to be estimated, $x_{1}, x_{2}, \ldots, x_{5}$ are natural factors that can be strictly controlled, and $\varepsilon_{i}$ are random variables that are independent of each other and obey the same normal distribution $N\left(0, \sigma^{2}\right)$.

This paper uses Origin software to perform multiple linear regression on the simulation results, and obtains the multiple linear regression equations between the building summer air conditioning cooling load and roof materials, outer window materials, building shading, shape coefficient, and window-wall ratio:

$$
\begin{gathered}
Y=8.740+0.747 X_{1}+0.172 X_{2}-4.826 X_{3}+ \\
0.776 X_{4}+14.525 X_{5}
\end{gathered}
$$

\subsubsection{Regression test}

The regression equation (2) obtained by the above hypothesis is tested to determine whether there is a linear relationship between the independent variable and the dependent variable.

(1) F test: select the significance level $\alpha$ to be 0.05 , and check the critical value $F \alpha$ from the $F$ distribution table. When $\mathrm{F}>\mathrm{F} \alpha$, the null hypothesis is rejected, and the result is $99.5 \%$ confident that the $\mathrm{F}$ value of the regression equation is

$$
F=5.906>F_{0.05}(5,10)=3.33
$$


Therefore, we are $99.5 \%$ confident that there is a significant linear relationship between the dependent variable $\mathrm{Y}$ and the independent variables $\mathrm{X}_{1}, \mathrm{X}_{2}, \mathrm{X}_{3}, \mathrm{X}_{4}$, and $\mathrm{X}_{5}$.

(2) P value test: If the associated probability $\mathrm{P}<0.05$ given by the $\mathrm{F}$ distribution table, reject the null hypothesis, and have $99.5 \%$ confidence in the result. The $\mathrm{P}$ value of the regression equation is

$$
P=0.009<\alpha=0.05
$$

Therefore, we are $99.5 \%$ confident that there is a significant linear relationship between the dependent variable $\mathrm{Y}$ and the independent variables $\mathrm{X}_{1}, \mathrm{X}_{2}, \mathrm{X}_{3}, \mathrm{X}_{4}$, and $\mathrm{X}_{5}$.

After the above two methods of testing, it can be proved that there is a significant linear relationship between the independent variable $\mathrm{Y}$ and the dependent variables $\mathrm{X}_{1}, \mathrm{X}_{2}, \mathrm{X}_{3}, \mathrm{X}_{4}$, and $\mathrm{X}_{5}$, and the regression equation meets the requirements.

\section{Conclusion}

Based on the results of the range analysis, the influence of building shading on the cooling load of summer air conditioning is the greatest, and the influence of other factors is arranged in order of shape coefficient $>$ outer window materials $>$ window-wall ratio $>$ roof materials $>$ outer wall materials.

Based on the results of the analysis of variance, the factors that have a highly significant impact on the change of air conditioning cooling load are building shading, shape coefficient and window-wall ratio, which are the primary considerations for building energy efficiency. The factors that have a significant impact are roof materials and outer window materials, which can be considered as auxiliary energy-saving measures. The impact of outer wall materials on the cooling load of air conditioning is smaller than other factors.

Based on the linear regression method, a simple calculation formula is proposed for the summer air conditioning cooling load of the teaching building. In the early design stage of a building, a few parameters can be input to quickly measure the building load and provide a reference for different energy-saving design schemes.

\section{Acknowledgments}

This study was financially supported by General project of science and technology plan of Beijing Municipal Commission of Education (110052972027/079).

\section{References}

1. Tan, H. W., Xu, Y. L., Hu, C. Y., Chen, X. L. (2010) Research on Building Campus Energy Management. Building Energy \& Environment, 29(01): 36-40.

2. Gao, B., Tan, H. W., Song, Y. C. (2011) Campus Building Energy Consumption: Taking one Comprehensive University as Example. Building
Energy Efficiency, 39(02): 41-44.

3. Luo, R. J. (2018) The Analysis and Strategy on Campus Energy Consumption in Cold Region. North China University of Science and Technology, Tangshan.

4. Ministry of Housing and Urban-Rural Development of the People's Republic of China. (2019) Assessment standard for green campus GB/T51356-2019. China Architecture \& Building Press, Beijing.

5. Yu, J., Yang, Z. W., Wang, C., Li, K. B. (2015) Simulation Analysis of Office Building Energy Consumption Based on DeST-C. Journal of Shenyang Jianzhu University (Natural Science), 31(04): 689-697.

6. Yang, W., Feng, G. C., Shi, D. X., Luo, Y. H., Zou, Y. R. (2014) Investigation on Energy consumption and Analysis of Energy Saving Strategies Case for One Large Public Building in Chengdu. Industrial Construction, 44(S1): 86-89+32.

7. Wang, R. J., Li, L. X. (2010) Study and Prediction on Heating Energy Consumption Based on Analysis of Variance for Residential Building. Building Energy Efficiency, 38(10): 50-52. 